\title{
DETECTION OF SPECIES-SPECIFIC AND CROSS-REACTIVE CELL-SURFACE ANTIGENS OF BACTEROIDES SPECIES BY AN INDIRECT ENZYME-LINKED IMMUNOSORBENT ASSAY
}

\author{
I. R. Poxton, R. Brown and J. G. Collee \\ Department of Bacteriology, University of Edinburgh Medical School, Teviot Place, \\ Edinburgh EH8 $9 A G$
}

\begin{abstract}
SUMMARY. EDTA-released outer-membrane antigen complexes were prepared from 172 laboratory and reference strains and 43 fresh clinical or faecal isolates representing 20 species or subspecies of Bacteroides, together with 13 species of other genera. These antigens were titrated against antisera to whole, live cells of 21 species or subspecies of Bacteroidaceae in an indirect enzyme-linked immunosorbent assay (ELISA). The presence of species-specific antigens was investigated and cross reactions between species were noted. Results showed that a high proportion of the species possess species-specific antigens with little significant cross reactivity.

We believe that the ELISA system described here detects antigens that represent the whole cell surface of bacteroides organisms. We have exploited the sensitivity of the system and its quantitative potential to define approaches for those wishing to use serological approaches for either the identification of Bacteroides species or for the titration of serum antibodies in patients with a possible bacteroides infection.
\end{abstract}

\section{INTRODUCTION}

In the laboratory investigation of infections involving anaerobes at mucosal surfaces, estimation of the numbers of the various organisms present, and a distinction between commensals and potential pathogens, could influence clinical assessment and management. In the development of this expertise, it would be helpful if diagnostic laboratories could identify bacteroides organisms to specific or subspecific level as a routine, but this is still a complex and time-consuming exercise. Although the direct observation of fluorescence of a specimen in ultraviolet light and the direct examination of pus by gas chromatography may be useful adjuncts to direct microscopy and may expedite the detection of anaerobes and the determination of the genera involved, more detailed identification still generally rests upon an extended series of biochemical and other tests (see Duerden et al., 1980).

Serological approaches to detailed identification of Bacteroides species and subspecies have been explored by several groups of workers (Beerens et al., 1971; 
Lambe and Jerris, 1976; Abshire, Lombard and Dowell, 1977; Elhag and Tabaqchali, 1978). Commercial kits have been developed (Holland, Stauffer and Altemeier, 1979; Labbé et al., 1980) and an immunoperoxidase method has been described (Hsu et al., 1979). Other workers have explored the possibility of detecting specific antibodies in the serum of patients with bacteroides infections (Hofstad, 1979; Sonnenwirth, 1979).

Our lack of knowledge of the significant surface antigens of these organisms in relation to existing and evolving taxonomic groupings limits the development of serological approaches to the characterisation of gram-negative anaerobes.

Outer membrane (OM) complexes released by EDTA from several species of Bacteroides have been shown to contain species-specific antigens that can be demonstrated by enzyme-linked immunosorbent assay (Poxton, 1979). The present study extends this investigation and examines cross reactions that may occur between species.

\section{MATERIALS AND METHODS}

The test bacteria included 172 strains representing 20 species or subspecies of Bacteroides, five strains of Capnocytophaga ochracea, six strains representing four species of Fusobacterium, and eight strains representing eight genera of aerobic or facultative gram-negative bacteria.

The following strains were obtained from the National Collection of Type Cultures (NCTC), Central Public Health Laboratory, Colindale Avenue, London NW9 5HT: Bacteroides fragilis NCTC nos. 9343, 9344, 8560, 10581 and 10584; B. thetaiotaomicron NCTC10582; B. vulgatus NCTC10583; B. eggerthi NCTC11155; B. splanchnicus NCTC nos. 10825 and 10826; B. melaninogenicus ss. intermedius NCTC nos. 9336 and 9338; B. asaccharolyticus NCTC9337; $B$. corrodens NCTC10939; Fusobacterium necrophorum NCTC nos. 10576 and 10577; F. necrogenes NCTC10723; $F$. polymorphum NCTC10562; $F$. varium NCTC10560; Proteus mirabilis NCTC6197; Salmonella abortus equi NCTC5727; Shigella sonnei NCTC8220; Escherichia coli NCTC10418; Pseudomonas aeruginosa NCTC10662; Enterobacter aerogenes NCTC8172; Branhamella catarrhalis NCTC3622 and Haemophilus influenzae NCTC4560.

B. melaninogenicus ss. melaninogenicus ATCC15930 was obtained from the American Type Culture Collection (ATCC), 12301 Parklawn Drive, Rockville, Md 20852. B. distasonis ATCC8503, B. ovatus ATCC8483 and B. uniformis ATCC8492 were from Dr Ella M. Barnes, Agricultural Research Council Food Research Institute, Colney Lane, Norwich. B. variabilis VPI11368, B. bivius VPI6318 and VPI6822, B. disiens VPI8057, B. melaninogenicus ss. melaninogenicus VPI4196 and B. melaninogenicus ss. levi VPI3300 were obtained from the Virginia Polytechnic Institute and State University (VPI), Blacksburg, Va. 24060. B. oralis strain 1210 was obtained from Dr S. Socransky, Forsythe Dental Center, Boston, Mass, and B. ruminicola NP333 was obtained from Dr G. H. Bowden, London Hospital Medical College. B. ureolyticus WPH58 was obtained from Dr A. L. James, Newcastle Polytechnic, Newcastle upon Tyne. Capnocytophaga ochracea (Ristella ochraceus) strain 1956c was obtained from Dr M. Sebald, Institut Pasteur, 25 Rue du Docteur Roux, Paris.

Other strains were received in connection with collaborative studies initiated by the ICSB, Taxonomic Sub-committee on Gram-negative Anaerobic Rods (see Holbrook, Duerden and Deacon, 1977; Deacon, Duerden and Holbrook, 1978), or were isolated in this laboratory from clinical material; 43 strains of Bacteroides spp. were isolated for use in the fresh isolate study (see below). All strains were identified by the methods of Duerden et al. $(1976,1980)$.

Growth of organisms and preparation of $O M$ antigens was modified from the method of Poxton (1979). Cultures in $50 \mathrm{ml}$ of PPY medium were incubated for up to $48 \mathrm{~h}$ to yield good growth. The suspended, washed cells were incubated with $10 \mathrm{~mm}$ EDTA at $45^{\circ} \mathrm{C}$ for $2.5 \mathrm{~h}$; after removal of cells by centrifugation, the undialysed supernate was used as the OM antigen.

Antisera were prepared as described by Poxton (1979).

Absorption of antisera. Cross-reacting antibodies were removed by incubating $1 \mathrm{ml}$ of serum with bacteria harvested from $50 \mathrm{ml}$ of an 18-h PPY culture and washed with phosphate-buffered saline. The suspension was shaken during the absorption period of $30 \mathrm{~min}$ at $37^{\circ} \mathrm{C}$ on a 
blood-cell suspension mixer. Cells were removed by centrifugation at $20000 \mathrm{~g}$ for $30 \mathrm{~min}$ at $4 \mathrm{C}$. The absorption procedure was repeated once.

Micro indirect enzyme-linked immunosorbent assay (ELISA) was modified from that of Poxton (1979). Considerable loss of protein can occur during dialysis and, because dialysed and undialysed OM antigens behaved similarly in the ELISA assay, undialysed preparations were used. No difference in homologous titre was generally found when the OM antigens were used at $30 \mu \mathrm{g}$ protein $/ \mathrm{ml}$ or $60 \mu \mathrm{g}$ protein $/ \mathrm{ml}$, so the lower concentration was used. However, for comparison with results already published by Poxton (1979) the 60- $\mu \mathrm{g}$ concentration was used in cross-reactivity studies. The results were read on a Titertek Multiscan Spectrophotometer (Organon Teknika, St Neots, Cambs); the highest dilution of serum that gave an $\mathrm{E}_{405}$ value $>1 \cdot 0$ was recorded as the titre.

Study of fresh isolates. Primary isolation plates from clinical specimens that contained anaerobic gram-negative rods, were kindly supplied from the Bacteriology Laboratory, Royal Infirmary of Edinburgh, and the Central Microbiology Laboratories, Western General Hospital, Edinburgh. When possible, a single colony was subcultured into $50 \mathrm{ml}$ of PPY medium and incubated for 18-48 h. This culture was checked for purity, then $5 \mathrm{ml}$ were lyophilised and the remaining $45 \mathrm{ml}$ were used for the preparation of OM antigen. If it was not possible to pick a single colony pure from the primary isolation plate, a subculture was made on BM-based lysed-blood agar containing kanamycin $75 \mu \mathrm{g} / \mathrm{ml}$ and vancomycin $2.5 \mu \mathrm{g} / \mathrm{ml}$ (Holbrook, Ogston and Ross, 1978). After incubation for $48 \mathrm{~h}$, a single colony was subcultured to PPY medium and processed as above.

$\mathrm{OM}$ antigens prepared from the fresh isolates were tested initially in a screening assay with selected pools of rabbit antisera before they were titrated against individual sera within any pool. A pool of antisera was prepared by mixing different volumes of saveral sera so that, when the pool was diluted and tested against its homologous OM antigens, they all reacted to the same titre. The pools were: $1, B$. fragilis group (BFG) comprising 11 sera; $2 \mathrm{a}$, B. melaninogenicus group (BMG, pigmented) comprising four sera; $2 \mathrm{~b}, B$. melaninogenicus group (BMG, non-pigmented) comprising six sera and 3 , asaccharolytic group (AG) comprising three sera.

$\mathrm{OM}$ antigens that reacted significantly in screening tests with the BFG pool were further screened against two other pools of BFG sera. They were: la, four sera representing three indole-negative Bacteroides species and $1 \mathrm{~b}$, seven sera representing six indole-positive Bacteroides species.

\section{RESULTS}

\section{Studies with $O M$ antigens and homologous sera}

Outer-membrane antigen preparations from 28 strains representing 23 species or subspecies of non-sporing anaerobes and one strain of Capno. ochracea were included in the indirect ELISA with antisera raised against the same strains, except for three of the Fusobacterium species, in rabbits and referred to here as species reference sera. OM antigen preparations from the eight control aerobic or facultative species were included in the study. The results are summarised in table I and the figure. Titres in the range 3200-51 200 were recorded for strictly homologous interactions, i.e., when an OM preparation was tested against a reference serum raised specifically against the same strain. Minor heterologous cross reactions were observed in some cases and are indicated as fractions of the homologous titres. When OM antigens from a range of strains within the same species were tested against the species reference antiserum, the results indicated the antigenic homogeneity or heterogeneity of the species (table I). Results obtained with reference and laboratory stock strains are analysed separately from those obtained with freshly isolated strains.

Results with reference and laboratory strains. OM antigen preparations from all B. fragilis, B. vulgatus, B. eggerthi, B. uniformis, B. splanchnicus, B. melaninogenicus ss. 


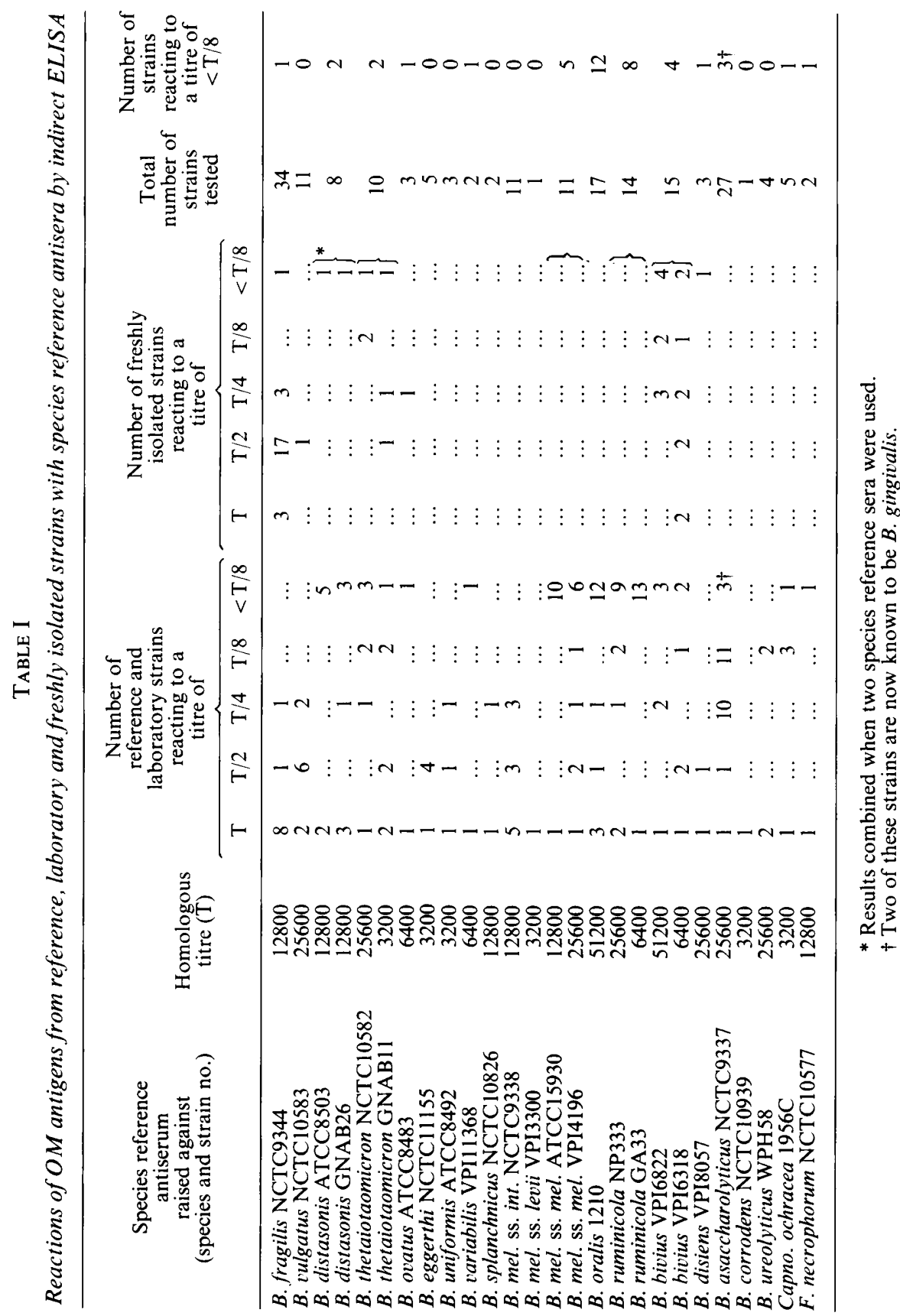


intermedius, and $B$. disiens strains reacted strongly with their respective species reference antisera. Two strains of $B$. ureolyticus reacted less strongly, but the reference serum did not cross react with any other species. Two strains labelled $B$. asaccharolyticus and later shown to be $B$. gingivalis did not react with the B. asaccharolyticus antiserum.

When it became apparent that some strains did not react with an antiserum prepared against the same species, sera were raised against other strains in an attempt to find a more representative strain or to determine whether more than one serogroup existed within the species. For example, strains of $B$. thetaiotaomicron reacted more uniformly and more strongly with GNAB 11 serum than with NCTC10582 serum, but one strain failed to react with either serum. Two strains of $B$. distasonis reacted with ATCC 8503 serum, and four other strains reacted with GNAB26 serum, but one strain failed to react with either serum. These findings indicate that there are two or more serogroups in each of these species. For some species or subspecies the small number of available test strains limited our study.

OM antigens from a significant proportion of the strains of $B$. melaninogenicus ss. melaninogenicus, $B$. oralis and $B$. ruminicola failed to react with their species reference antisera. Six of 11 strains of $B$. melaninogenicus ss. melaninogenicus, 12 of 17 strains of $B$. oralis and eight of 14 strains of $B$. ruminicola failed to react with their species reference antisera.

Results with freshly isolated strains. After the OM antigens prepared from fresh isolates had been screened against pooled sera (see Methods) the following results were obtained with appropriate species reference sera (table I): 23 out of 24 strains of $B$. fragilis, one strain of $B$. vulgatus, two of three strains of $B$. thetaiotaomicron, one strain of $B$. ovatus and seven out of nine strains of $B$. bivius reacted to a titre one-eighth or greater of the respective homologous titres. However, one strain each of $B$. fragilis, $B$. distasonis, $B$. thetaiotaomicron and B. disiens, and two strains of $B$. bivius failed to react with their species reference sera. Three strains that failed to react with any group of pooled antisera were later identified as $B$. capillosus for which we do not have an antiserum. The OM antigen prepared from B. bivius GNAB136 reacted significantly with more than one serum; it reacted to half of the homologous titre with the species reference serum (VPI6318) and to one-eighth of the homologous titres with the $B$. disiens VPI8057 serum and the $B$. oralis 1210 serum.

\section{Cross reactions between species}

B. fragilis group (BFG) $O M$ antigens. When $\mathrm{OM}$ antigens from 11 strains representing the nine species comprising the $\mathrm{BFG}$ were titrated with rabbit antisera raised against washed whole bacteria, homologous titres were significantly greater and usually at least 16-fold greater than any heterologous cross reactions (figure). However, there were four reactions between BFG OM antigens and BFG sera, in which the difference was 16 -fold or less; there were significant cross reactions between a $B$. ovatus antigen and the two $B$. thetaiotaomicron antisera, a $B$. uniformis antigen and a $B$. fragilis serum and a $B$. variabilis antigen and a $B$. eggerth $i$ serum. In addition, three BFG OM antigens cross reacted with $B$. melaninogenicus/B. oralis/B. ruminicola group antisera to one-sixteenth of the homologous titre. Serum raised against Capno. ochracea cross reacted with the OM antigen from B. distasonis GNAB26. 


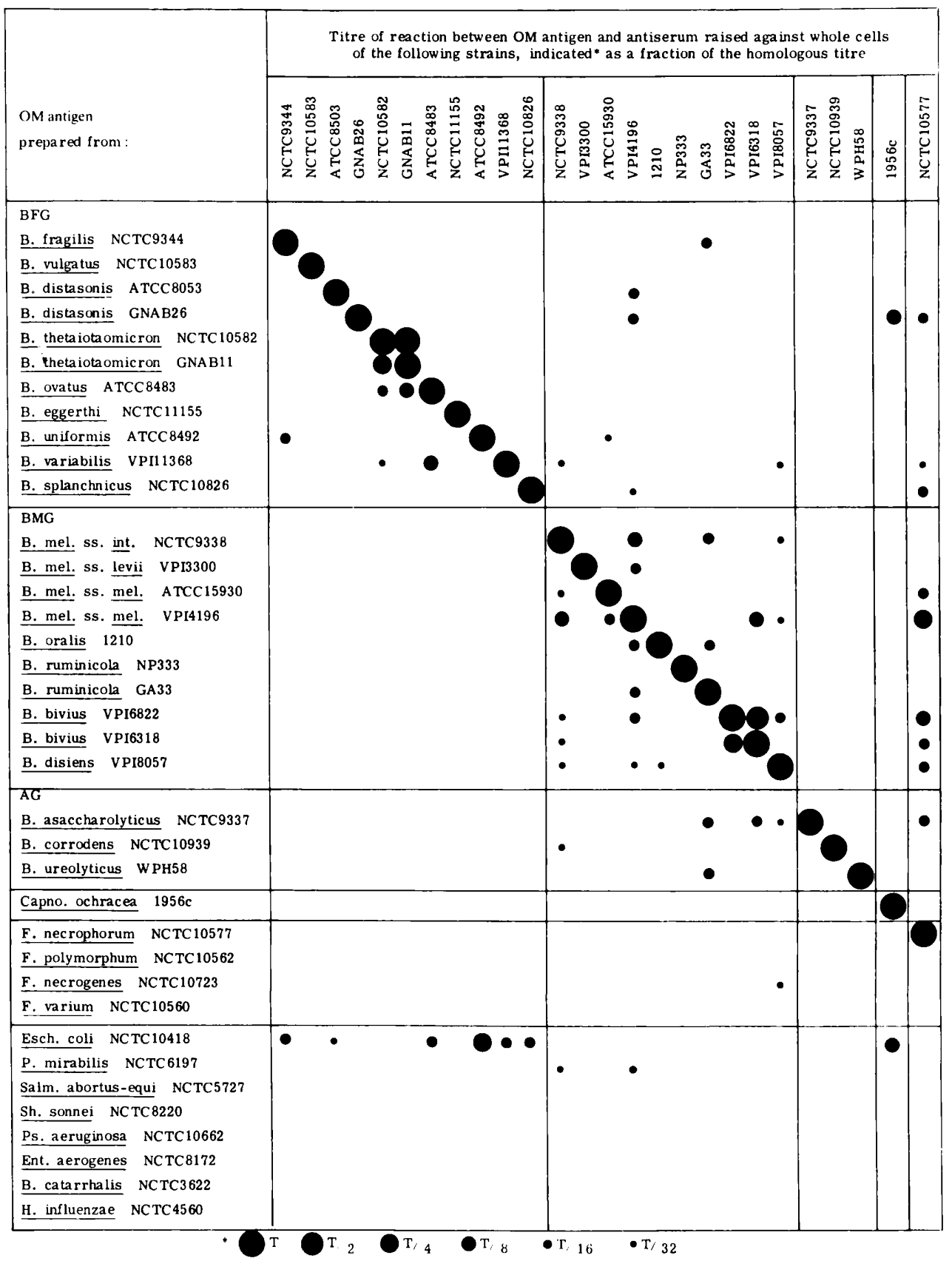

FIG.- Specificity of the interaction of $O M$ antigens and antisera prepared from bacteroides and other organisms in an indirect ELISA system. $\mathrm{BFG}=B$. fragilis group; $\mathrm{BMG}=\boldsymbol{B}$. melaninogenicus/oralis/ ruminicola group; $\mathrm{AG}=$ asaccharolytic group. 
B. melaninogenicus/oralis/ruminicola group (BMG) $O M$ antigens. The $\mathrm{OM}$ antigens of this group did not cross react with antisera raised against species in the $\mathrm{BFG}$ or the asaccharolytic group. When these $\mathrm{OM}$ antigens were titrated against antisera raised against the BMG species there was usually at least a 16-fold difference between the homologous and cross-reacting titres, but there were 12 cross reactions where the difference was 16-fold or less (figure).

Asaccharolytic group (AG) OM antigens. OM antigens of this group did not cross react with antisera raised against species in the BFG or AG series, but there were some minor cross reactions with antisera raised against the BMG species (figure).

$O M$ antigens of aerobic and facultative gram-negative bacilli. $\mathrm{OM}$ antigens from these organisms usually failed to react with the bacteroides antisera or reacted to less than one-sixteenth of the homologous titre. The exception was the OM antigen from Esch. coli NCTC10418 which reacted with some of the BFG and AG antisera and the Capno. ochracea antiserum to a titre one-sixteenth or greater of the homologous titre, but did not react with the BMG antisera.

Cross reactions with Fusobacterium necrophorum antiserum. Serum raised against $F$. necrophorum cross reacted with many OM antigens prepared from Bacteroides spp. but not with the OM antigens of other Fusobacterium spp.

Reactions with absorbed antisera. After absorption of cross-reacting antibodies (see Methods) the heterologous titres of 10 out of 13 cross-reacting sera were reduced to $<400$ with no more than a twofold decrease in the homologous titres (table II).

TABLE II

Absorption of cross-reacting antibodies by treatment of antiserum with whole cells of cross-reacting strains

\begin{tabular}{|c|c|c|c|c|c|}
\hline \multirow{2}{*}{$\begin{array}{l}\text { Antiserum } \\
\text { raised } \\
\text { against } \\
\text { strain }\end{array}$} & \multirow{2}{*}{$\begin{array}{l}\text { Cross-reacting } \\
\text { antigen from } \\
\text { strain }\end{array}$} & \multicolumn{2}{|c|}{$\begin{array}{l}\text { Titre when homologous } \\
\text { antigen was reacted with: }\end{array}$} & \multicolumn{2}{|c|}{$\begin{array}{l}\text { Titre when cross-reacting } \\
\text { antigen was reacted with: }\end{array}$} \\
\hline & & $\begin{array}{l}\text { unabsorbed } \\
\text { serum }\end{array}$ & $\begin{array}{l}\text { serum absorbed with } \\
\text { whole cells of cross- } \\
\text { reacting strain }\end{array}$ & $\begin{array}{l}\text { unabsorbed } \\
\text { serum }\end{array}$ & $\begin{array}{l}\text { serum absorbed with } \\
\text { whole cells of cross- } \\
\text { reacting strain }\end{array}$ \\
\hline NCTC9344 & ATCC 8492 & 6400 & 3200 & 400 & $<400$ \\
\hline NCTC 10582 & ATCC 8483 & 25600 & 25600 & 1600 & $<400$ \\
\hline GNAB 11 & ATCC 8483 & 3200 & 3200 & 400 & $<400$ \\
\hline NCTC 11155 & VPI1 1368 & 6400 & 3200 & 400 & $<400$ \\
\hline ATCC 8492 & NCTC10418 & 12800 & 12800 & 3200 & $<400$ \\
\hline NCTC 9338 & VPI4196 & 25600 & 25600 & 6400 & $<400$ \\
\hline VPI4196 & NCTC 9338 & 51200 & 51200 & 3200 & $<400$ \\
\hline VPI4196 & ATCC 8503 & 25600 & 12800 & 1600 & 800 \\
\hline VPI4196 & GNAB26 & 25600 & 12800 & 1600 & 800 \\
\hline VPI4196 & VPI3300 & 25600 & 25600 & 1600 & 800 \\
\hline VPI4196 & 1210 & 25600 & 12800 & 1600 & $<400$ \\
\hline VPI4196 & VPI8057 & 25600 & 12800 & 800 & $<400$ \\
\hline 1210 & VPI8057 & 25600 & 12800 & 1600 & $<400$ \\
\hline VPI6318 & VPI4196 & 12800 & 6400 & 1600 & $<400$ \\
\hline VPI8057 & NCTC9338 & 12800 & 12800 & 400 & $<400$ \\
\hline
\end{tabular}

\section{DisCUSSION}

We have shown here, and previously (Poxton, 1979), that Bacteroides species generally have cell-surface antigens that are species specific. The cross reactions that do occur are mainly between similar species; cross-reactive antibodies can be absorbed 
with whole cells of the cross-reactive species. Our results suggest that it will be possible to define species-specific surface antigens for many species of Bacteroides especially within the $\boldsymbol{B}$. fragilis group. This has already been done for $\boldsymbol{B}$. vulgatus where the species-specific antigen is the major outer-membrane protein (Poxton and Ip, 1981) and for $B$. fragilis where the "capsular" polysaccharide, which appears to be membrane bound and is thus amenable to investigation by ELISA, is the speciesspecific antigen (Kasper et al., 1977). More strains within the species $B$. bivius, $B$. melaninogenicus ss. intermedius, $B$. asaccharolyticus and $B$. ureolyticus also appear to possess species-specific or subspecies-specific antigens. Some species such as $B$. melaninogenicus ss. melaninogenicus, $B$. oralis and $B$. ruminicola, are as yet ill defined and there were significant cross reactions within the group; more taxonomic studies must be made before this group can be investigated serologically. For other species, we have not been able to obtain sufficient strains to make a full serological investigation.

In any identification scheme based on serological techniques, the antigens that are to be detected must be clearly defined; their predominance within a species, subspecies or serogroup should be known, and their cross reactions with related and unrelated species must be determined. Moreover, the stability of these antigens and their expression in laboratory-passaged strains must be ascertained. Only one of 24 fresh isolates of $B$. fragilis failed to react with the $B$. fragilis species reference serum. More work is needed to evaluate the significance of the few non-reactors when small numbers of fresh isolates of other species were tested against apparently appropriate species reference sera. A cautious approach to the identification of wild strains by sera raised against stock strains is clearly advisable on principle, but the results with $B$. fragilis strains are particularly encouraging.

The indirect enzyme-linked immunosorbent assay that we used has provided useful results in our investigation of material released from bacteria by mild heat, EDTA and sonication. Our system appears to provide a valid representation of all of the antigens present at the surface of whole cells. The antigens detected could include protein, lipopolysaccharide (LPS) and capsular material; because extremely high dilutions of serum are used, the system will detect the more immunogenic molecules, which have the greatest affinity for the antibodies that we raised against whole cells. Less immunogenic molecules which may be more cross reactive, such as LPS (Elhag and Tabaqchali, 1978), will not be detected at such high dilutions of serum. The extreme sensitivity of the system, its specificity and its quantitative potential will be of use in defining approaches that might exploit immunofluorescence methods for the direct examination of clinical specimens, or might allow the titration of serum antibodies in patients with a possible bacteroides infection.

This study was supported by the Medical Research Council (Grant No. G977/951/S).

\section{REFERENCES}

AbShiRe, R. L., Lombard, G. L. AND Dowell, V. R. 1977. Fluorescent antibody studies on selected strains of Bacteroides fragilis subspecies fragilis. J. clin. Microbiol., 6, 425.

Beerens, H., Wattre, P., Shinjo, T. and Romond, C. 1971. Premiers résultats d'un essai de classification sérologique de 131 souches de Bacteroides du groupe fragilis (Eggerthella). Annls Inst. Pasteur, Paris, 121, 187.

Deacon, A. G., Duerden, B. I. And Holbrook, W. P. 1978. Gas-liquid chromatographic 
analysis of metabolic products in the identification of Bacteroidaceae of clinical interest. $J$. med. Microbiol., 11, 81 .

Duerden, B. I., Collee, J. G., Brown, R., Deacon, A. G. and Holbrook, W. P. 1980. A scheme for the identification of clinical isolates of gram-negative anaerobic bacilli by conventional bacteriological tests. J. med. Microbiol., 13, 231.

Duerden, B.I., Holbrook, W. P., Collee, J. G. And Watt, B. 1976. The characterization of clinically important gram-negative anaerobic bacilli by conventional bacteriological tests. J. appl. Bact., 40, 163.

ElhaG, K. M. AND TABaQChali, S. 1978. A study of the surface and somatic antigens of Bacteroides fragilis. J. Hyg., Camb., 80, 439.

Hofstad, T. 1979. Serological responses to antigens of Bacteroidaceae. Microbiol. Rev., 43, 103.

Holbrook, W. P., Duerden, B. I. And Deacon, A. G. 1977. The classification of Bacteroides melaninogenicus and related species. J. appl. Bact., 42, 259.

Holbrook, W. P., Ogston, S. A. and Ross, P. W. 1978. A method for the isolation of Bacteroides melaninogenicus from the human mouth. J. med. Microbiol., 11, 203.

Holland, J. W., Stauffer, L. R. And Altemeier, W. A. 1979. Fluorescent antibody test kit for rapid detection and identification of members of the Bacteroides fragilis and Bacteroides melaninogenicus groups in clinical specimens. J. clin. Microbiol., 10, 121.

Hsu, P. C., Minshew, B. H., Williams, B. L. and Lennard, E. S. 1979. Use of an immunoperoxidase method for identification of Bacteroides fragilis. J. clin. Microbiol., 10, 285.

Kasper, D. L., Hayes, M. E., Reinap, B. G., Craft, F. O., Onderdonk, A. B. and Polk, B. F. 1977. Isolation and identification of encapsulated strains of Bacteroides fragilis. J. infect. Dis., 136, 75.

Labbé, M., Delamare, N., Pepersack, F., Crokaert, F. and Yourassowsky, E. 1980. Detection of Bacteroides fragilis and Bacteroides melaninogenicus by direct immunofluorescence. J. clin. Path., 33, 1189.

Lambe, D. W. AND JeRRIS, R. C. 1976. Description of a polyvalent conjugate and a new serogroup of Bacteroides melaninogenicus by fluorescent antibody staining. J. clin. Microbiol., 3, 506.

Poxton, I. R. 1979. Serological identification of Bacteroides species by an enzyme-linked immunosorbent assay. J. clin. Path., 32, 294.

Poxton, I. R. AND IP, M. K.-Y. 1981. The cell surface antigens of Bacteroides vulgatus. J. gen. Microbiol., 126, 103.

Sonnenwirth, A. C. 1979. Antibody response to anaerobic bacteria. Rev. infect. Dis., 1, 337. 